\title{
Higher plant diversity promotes higher diversity of fungal pathogens, while it decreases pathogen infection per plant
}

\author{
Tanja Rottstock, ${ }^{1,5}$ Jasmin Joshi, ${ }^{1,2}$ Volker Kummer, ${ }^{1}$ and Markus Fischer ${ }^{3,4}$ \\ ${ }^{1}$ Institute of Biochemistry and Biology, Biodiversity Research/Systematic Botany, University of Potsdam, Maulbeerallee 1, \\ 14469 Potsdam, Germany \\ ${ }^{2}$ Berlin-Brandenburg Institute of Advanced Biodiversity Research (BBIB), 14195 Berlin, Germany \\ ${ }^{3}$ Institute of Plant Sciences, University of Bern, Altenbergrain 21, 3013 Bern, Switzerland \\ ${ }^{4}$ Biodiversity and Climate Institute BiK-F, Senckenberg Gesellschaft für Naturforschung, Frankfurt, Germany
}

\begin{abstract}
Fungal plant pathogens are common in natural communities where they affect plant physiology, plant survival, and biomass production. Conversely, pathogen transmission and infection may be regulated by plant community characteristics such as plant species diversity and functional composition that favor pathogen diversity through increases in host diversity while simultaneously reducing pathogen infection via increased variability in host density and spatial heterogeneity. Therefore, a comprehensive understanding of multi-hostmulti-pathogen interactions is of high significance in the context of biodiversity-ecosystem functioning. We investigated the relationship between plant diversity and aboveground obligate parasitic fungal pathogen ("pathogens" hereafter) diversity and infection in grasslands of a long-term, large-scale, biodiversity experiment with varying plant species (160 species) and plant functional group diversity (1-4 groups). To estimate pathogen infection of the plant communities, we visually assessed pathogen-group presence (i.e., rusts, powdery mildews, downy mildews, smuts, and leaf-spot diseases) and overall infection levels (combining incidence and severity of each pathogen group) in 82 experimental plots on all aboveground organs of all plant species per plot during four surveys in 2006.

Pathogen diversity, assessed as the cumulative number of pathogen groups on all plant species per plot, increased log-linearly with plant species diversity. However, pathogen incidence and severity, and hence overall infection, decreased with increasing plant species diversity. In addition, co-infection of plant individuals by two or more pathogen groups was less likely with increasing plant community diversity. We conclude that plant community diversity promotes pathogen-community diversity while at the same time reducing pathogen infection levels of plant individuals.
\end{abstract}

Key words: biodiversity; ecosystem processes; ecosystem services; grasslands; multi-host-multipathogen interactions; obligate parasitic fungal pathogens; pathogen diversity; pathogen proneness; pathogen transmission; plant functional types.

\section{INTRODUCTION}

Effects of decreasing plant diversity on other taxa including invading plants (Joshi et al. 2000, van Ruijven et al. 2003, Scherber et al. 2010a, $b$ ), herbivores (Mulder et al. 1999, Koricheva et al. 2000, Haddad et al. 2011), and pathogens (Knops et al. 1999, Keesing et al. 2010) have become important research priorities in ecology (Mace et al. 2010, Scherber et al. 2010a). Traditionally, pathogens have mainly been studied in single-hostsingle-pathogen experiments providing highly detailed information on individual host-pathogen interactions such as pathogen virulence and plant susceptibility (Pfleeger and Mundt 1998, Burdon et al. 2006, Keesing et al. 2006) reflecting shared coevolution (Krupinsky et

Manuscript received 16 December 2013; accepted 23 December 2013; final version received 4 February 2014. Corresponding Editor: B. A. Roy.

${ }^{5}$ E-mail: Tanja.Rottstock@uni-potsdam.de al. 2002). However, these single-host-single-pathogen studies cannot cover the species diversity and spatial complexity of natural plant assemblages (Mundt et al. 2011). Thus, the characterization of multi-host-multipathogen associations is needed to comprehensively understand biotic and abiotic interactions to reliably predict pathogen infections of natural communities under changing species diversity (Roy et al. 2004, Alexander 2010).

Natural plant communities typically consist of numerous plant species, are genetically diverse, and spatially complex with plant density and individual morphologies influenced by complementarity, facilitation, and competitive plant species interactions (Hooper 1998, Fargione et al. 2007, Cardinale et al. 2011) as well as by abiotic conditions such as soil nutrient availability and microclimate (Gubsch et al. 2011, Flombaum and Sala 2012). Thus, plant communities may differentially affect the presence, infection, and diversity of plant pathogens (Keesing et al. 2010, Scherber et al. 2010a) via 
abundance and spatial distribution of susceptible and resistant genotypes, and of structural three-dimensional space-filling components (Garrett and Mundt 1999, Altizer et al. 2003, Alexander 2010, King and Lively 2012). Plant community diversity can affect both pathogen communities and host-pathogen dynamics (Mitchell et al. 2002, Ferrer and Gilbert 2003, Mitchell 2003, Keesing et al. 2006, 2010). The increased number of potential host species may enable a diverse pathogen community of specialized pathogens (Hudson et al. 2006) while also supporting the presence of generalists (Gilbert 2002, Keesing et al. 2006). In addition, the coexistence and performance of plant species within communities may regulate initial pathogen infection and further pathogen transmission between adjacent host individuals through host encounter, i.e., host density, host spatial distribution, and host proneness (Elton 1958, Knops et al. 1999, Burdon et al. 2006). The likelihood of encountering susceptible host individuals is strongly dependent on host density (Mitchell and Power 2006, Mundt et al. 2011), which might be lower if plant species diversity and evenness of a community are high. Previous studies observed positive host-density correlations especially for aerial and splash dispersed aboveground fungal pathogens as well as some vectortransmitted viruses (Elton 1958, Burdon and Chilvers 1982, Borer et al. 2009, Moore and Borer 2012) linking host density to diversity of pathogen infections (Knops et al. 1999, Carlsson-Granér and Thrall 2002, Mitchell et al. 2002, Joshi et al. 2004, Adler and Mueller-Landau 2005, Johnson et al. 2008, Blaisdell and Roy 2013). Individual host properties including nutrient state of plant tissue and defense levels (Chen et al. 2010) and pathogen range and transmission mode (Kranz 1990, Borer et al. 2009, Moore and Borer 2012, Skelsey et al. 2013) including the diversity, abundance, or behavior of pathogen vectors can also be influenced by plant species diversity (Burdon and Chilvers 1982, Kranz 1990, Latz et al. 2012). Higher community biomass, increased vegetation cover and primary productivity with increasing plant species diversity (Spehn et al. 2000, Marquard et al. 2009b) indirectly influence the microclimate (i.e., temperature and humidity) and both plant defense and compensation ability (Altizer and Pedersen 2008, Ney et al. 2013) thus affecting plant-pathogen interactions (Kranz 1990, Burdon et al. 2006). Despite all these studies mentioned above, generalization and predictability of community based multi-host-multi-pathogen interactions has proven difficult so far.

We used local mesophilic grassland communities in a well-established, long-term, large-scale, grassland biodiversity experiment in Jena, Germany (Weigelt et al. 2010) to investigate the effect of varying plant species diversity and functional composition on pathogen presence, infection and diversity. In contrast to previous studies, we did not limit our observations to a restricted number of host species with their associated pathogens nor did we focus on few specific pathogen species, but addressed the interactions of multiple plant hosts with multiple pathogens as comprehensively as possible at the community level. In our experimental grassland communities, plant community composition, plant species richness (1-60 species), and plant functional group diversity levels (1-4 groups) were systematically varied and replicated in a randomized block design (Roscher et al. 2004). Our experimental design not only allowed us to test the impact of plant diversity (both species and functional), but also to separate the effects of the presence of individual plant functional groups on pathogen presence and infection.

We assessed the pathogen community at the pathogen group level in each experimental plant community and studied the role of plant community composition and of plant species and plant functional diversity for pathogen presence, infection, and diversity. Earlier work with the Jena Experiment reported increasing plant species diversity to increase overall community biomass, individual plant height, leaf area and plant cover, while decreasing plant species density (Marquard et al. 2009a, Schmidtke et al. 2010, Weigelt et al. 2010). Thus, we expected pathogen infection-levels per plant to decrease due to reduced realized host density in diverse plant communities. Additionally, we hypothesized that high plant diversity promotes pathogen diversity due to increased host availability.

\section{Material And Methods \\ Experimental design}

The Jena Experiment is a large-scale biodiversity experiment addressing the impact and consequences of plant species diversity on ecosystem processes since 2002 (Roscher et al. 2004). It is located on a former arable field on the floodplain of the river Saale, close to the city of Jena, Germany $\left(50^{\circ} 55^{\prime} \mathrm{N}, 11^{\circ} 35^{\prime} \mathrm{E}, 130 \mathrm{~m}\right.$ above sea level). In a multivariate statistical assessment, four functional groups (grasses, small herbs, tall herbs, and legumes) of a pool of 60 local mesophilic grassland species of the Arrhenatherion alliance were distinguished based on life-history and morphological characteristics (Roscher et al. 2004). Plant communities of up to all 60 plant species were established in spring 2002 and plant species richness (1, 2, 4, 8, 16, 60 species) as well as functional diversity levels $(1,2,3,4$ plant functional groups) were systematically varied and replicated in a randomized block design. A total of 82 plots were randomly attributed to the different diversity levels in four blocks with the restriction of equal numbers of plots and replicates per diversity level within each block. The $20 \times 20 \mathrm{~m}$ plots were each subdivided into a core area $(10 \times 15 \mathrm{~m})$ and surrounding smaller subareas (Roscher et al. 2004). To maintain the sown diversity levels, plots were weeded twice a year in April and July. All plots were mown in June and September, according to the typical management of such meadows in this area. 
TABle 1. Definition of key terms used in text.

\begin{tabular}{ll}
\hline \hline \multicolumn{1}{c}{ Variables } & \multicolumn{1}{c}{ Description } \\
\hline $\begin{array}{l}\text { Obligate parasitic fungal pathogens } \\
\text { Pathogen }\end{array}$ & $\begin{array}{l}\text { Fungi that require living plant tissue in order to survive and reproduce. } \\
\text { An entity that can incite disease. In our text, shortcut for "obligate parasitic fungal } \\
\text { plant pathogens." } \\
\text { Taxonomic grouping, i.e., rusts (RU), powdery and downy mildews (PM, DM), } \\
\text { fungal caused leaf spot diseases (LFS), and smuts (SM). } \\
\text { Establishment of a pathogen in a host, here measured as pathogen incidence, severity, } \\
\text { and as combination of both as overall infection. }\end{array}$ \\
Pathogen infection & $\begin{array}{l}\text { Presence of more than one pathogen group per plant species and plot. } \\
\text { Presence/absence as 1/0 of a fungal pathogen group on host species. }\end{array}$ \\
Co-infection & Cumulative number of pathogen groups per species and plot. \\
Pathogen presence & Mean percentage of infected plant individuals per species, pathogen group, and plot. \\
Pathogen diversity & Mean percentage of infected plant tissue per species, pathogen group, and plot. \\
Pathogen incidence & Sum of (pathogen severity $\times$ pathogen incidence) of all pathogen groups per species \\
Pathogen severity & and plot.
\end{tabular}

\section{Pathogen monitoring}

In 2006, we surveyed the pathogen infection of all plant species in an assigned subarea $(2 \times 4 \mathrm{~m})$ in each of the 82 plots $(20 \times 20 \mathrm{~m})$. We focused on the pathogen groups of rusts (RU), powdery mildews (PM), downy mildews (DM), smuts (SM) and, in addition, on the heterogeneous group of fungal leaf-spot diseases (LFS).

Four surveys were conducted in 2006, "spring assessment" in May, "early and late summer assessment" in June and August at vegetation maximum before the first and second cut, respectively, and "autumn assessment" in mid-October, to cover most of the vegetation period and potential within-year pathogen fluctuations in the plant communities. We detected infection by rusts, downy mildew and smuts as visible occurrence of sporulation structures, infection by powdery mildews as presence of mycelium and infection by leaf-spot diseases as occurrence of necrotic leaf lesions.

In each survey, we visually examined all aboveground plant organs (stems, leaves, inflorescences) of at least 10 plant individuals per species and plot. We consistently recorded along three transects of $4 \mathrm{~m}$ each, thus covering the entire subplot $(2 \times 4 \mathrm{~m})$, the number and identity of infected, uninfected, and missing plant species and assessed the presence, incidence, and severity of all pathogen groups for all plant species.

Obligate parasitic fungal pathogens vary widely in their impact and rarely kill their hosts. We therefore evaluated the two standard variables in phytopathological epidemiology, pathogen incidence and pathogen severity, for the assessment of obligate fungal pathogens for all plant species and plots directly in the field. Pathogen incidence (Trigiano et al. 2004, Agrios 2005) for each pathogen group per host species and plot was estimated as the mean percentage of infected individuals per species and plot (Table 1). Likewise, pathogen severity of each pathogen group was measured based on a rating scheme after Oberforster (2001), as the mean percentage of infected plant tissue per plant and plot (Table 1; Trigiano et al. 2004, Agrios 2005). To estimate community pathogen load, we calculated overall infection per plot by multiplying pathogen incidences with pathogen severities and summing up these results per pathogen group, host species, and plot.

We aimed at maximizing our number of replicate measurements in the field at a minimum of time delay between the first and last plot sampled (Snedecor and Cochran 1980). However, pathogen species diversity cannot be evaluated directly in the field as sporulation structures within pathogen groups are morphologically similar and cannot be distinguished with the naked eye. Only very few pathogen species can be directly identified in the field while the vast majority require determination by microscope. In contrast, individual pathogen groups can be easily assigned in the field due to distinct morphological and life-history characteristics and pathogen species can be clearly attributed to a specific pathogen groups. Hence, we used the presence of pathogen groups to estimate pathogen diversity as the cumulative number of pathogen groups present per host species and plot. We are aware that this approach might potentially underestimate real pathogen diversity, yet it minimizes errors due to incorrectly identifying pathogen species and overlooking rare pathogen species.

However, to obtain an overall pathogen species list for each plant species for the entire field site across diversity levels and survey time, we collected one sample of infected plant tissue per plant species and pathogen group in all plots and confirmed pathogen identity at the species level in the lab. For identification to species, samples were examined using a Zeiss Axioscope light microscope (Carl Zeiss, Jena/Oberkochen, Germany). Taxonomy and degree of pathogen specialization followed Gäumann (1959), Schüepp (1959), Braun (1982, 1995a,b), Brandenburger (1985), Vánky (1994), Ellis and Ellis (1997), Klenke (1998), and Braun and Cook (2012).

\section{Statistical analysis}

All statistical analyses were carried out with $\mathrm{R}$, Version 2.6.1 ( $\mathrm{R}$ Development Core Team 2008). To account for temporal pseudoreplication of measure- 
TABLE 2. Summary of generalized linear model (GLM) results for effects of plant community diversity and composition on (a) pathogen presence/absence across seasons and (b) occurrence of multiple pathogen-group infections (i.e., co-infection) across seasons.

\begin{tabular}{|c|c|c|c|c|c|c|c|c|c|c|c|c|}
\hline \multirow[b]{2}{*}{ Source of variance } & \multicolumn{3}{|c|}{ Spring } & \multicolumn{3}{|c|}{ Early summer } & \multicolumn{3}{|c|}{ Late summer } & \multicolumn{3}{|c|}{ Autumn } \\
\hline & df & $F$ & $P$ & df & $F$ & $P$ & df & $F$ & $P$ & df & $F$ & $P$ \\
\hline \multicolumn{13}{|c|}{ a) Pathogen presence/absence } \\
\hline Block & 3 & 2.22 & 0.097 & 3 & 0.05 & 0.984 & 3 & 1.71 & 0.173 & 3 & 0.81 & 0.491 \\
\hline $\log$ (species diversity) & 1 & 28.79 & $<0.001$ & 1 & 25.61 & $<0.001$ & 1 & 53.40 & $<0.001$ & 1 & 58.28 & $<0.001$ \\
\hline Functional diversity & 1 & 0.56 & 0.458 & 1 & 0.07 & 0.792 & 1 & 0.28 & 0.599 & 1 & 0.08 & 0.780 \\
\hline Functional diversity & 1 & 5.41 & 0.024 & 1 & 12.08 & 0.001 & 1 & 26.15 & $<0.001$ & 1 & 26.11 & $<0.001$ \\
\hline log (species diversity) & 1 & 23.94 & $<0.001$ & 1 & 13.60 & $<0.001$ & 1 & 27.54 & $<0.001$ & 1 & 32.25 & $<\mathbf{0 . 0 0 1}$ \\
\hline Presence legumes & 1 & 5.79 & 0.020 & 1 & 12.16 & 0.001 & 1 & 6.21 & 0.015 & 1 & 0.01 & 0.926 \\
\hline Presence grass & 1 & 0.39 & 0.538 & 1 & 2.26 & 0.137 & 1 & 0.59 & 0.445 & 1 & 0.65 & 0.421 \\
\hline Presence tall herbs & 1 & 0.78 & 0.381 & 1 & 0.52 & 0.472 & 1 & 3.64 & 0.060 & 1 & 0.01 & 0.926 \\
\hline Plot & 52 & & & 73 & & & 73 & & & 73 & & \\
\hline \multicolumn{13}{|c|}{ b) Occurrence of multiple pathogen-group infections } \\
\hline Block & 3 & 1.02 & 0.394 & 3 & 1.52 & 0.217 & 3 & 0.89 & 0.449 & 3 & 2.711 & 0.051 \\
\hline $\log$ (species diversity) & 1 & 5.54 & 0.022 & 1 & 9.74 & 0.003 & 1 & 19.56 & $<0.001$ & 1 & 10.743 & 0.002 \\
\hline Functional diversity & 1 & 4.97 & 0.03 & 1 & 0.12 & 0.733 & 1 & 1.04 & 0.312 & 1 & 0.755 & 0.388 \\
\hline Functional diversity & 1 & 0.19 & 0.669 & 1 & 5.29 & 0.024 & 1 & 4.58 & 0.036 & 1 & 2.398 & 0.126 \\
\hline $\log$ (species diversity) & 1 & 10.52 & 0.002 & 1 & 4.72 & 0.033 & 1 & 17.4 & $<\mathbf{0 . 0 0 1}$ & 1 & 9.101 & 0.004 \\
\hline Presence legumes & 1 & 1.55 & 0.219 & 1 & 0.11 & 0.744 & 1 & 3.77 & 0.056 & 1 & 7.428 & 0.008 \\
\hline Presence grass & 1 & 0.00 & 0.957 & 1 & 0.10 & 0.755 & 1 & 0.05 & 0.82 & 1 & 0.008 & 0.927 \\
\hline Presence tall herbs & 1 & 0.23 & 0.635 & 1 & 0.05 & 0.825 & 1 & 0.09 & 0.77 & 1 & 0.478 & 0.491 \\
\hline Plot & 52 & & & 77 & & & 76 & & & 71 & & \\
\hline
\end{tabular}

Notes: Values for functional and species diversity in boldface type were derived from otherwise identical models with reversed sequence of functional and species diversity. Plot rows show error df.

ments, all seasons were analyzed separately. All percentage data were arcsine transformed to meet the assumptions of normality and homoscedasticity. We analyzed the presence/absence of pathogen groups per species and plot using a generalized linear model (GLM) with binomial error distribution and sequential sums of squares with the following sequence of factors: block, $\log$ (species diversity), functional diversity, presence of legumes, presence of grasses, presence of tall herbs and plot as error term (see Marquard et al. 2009b; Table 2).

For the response variables pathogen diversity, overall infection, pathogen incidence, and pathogen severity, we used mixed-effects models (Table 3, Appendix A) with block, plot identity, and species identity as random effects (Schmidtke et al. 2010). The sequential model included the following factors: block, $\log$ (species diversity), functional diversity, presence of legumes, presence of grasses, presence of tall herbs, plot identity, plant functional group identity (as factor), plant species identity (as factor), and all interaction terms. The nesting structure of our data (plant species within plots) was fully acknowledged and $P$ and $F$ values were calculated accordingly. In particular, we tested effects of community diversity and composition against the plot level (Schmidtke et al. 2010). Seasonal differences in the apparency of plant species resulted in slight differences in residual numbers of degrees of freedoms in ANOVA tables of analyses including species identity. To further distinguish species diversity effects on pathogen presence and infection, we incorporated plant species cover as a measure for plant species density data evaluated on the same plots in the same year as covariate in an alternative model (Marquard et al. 2009a).

We tested all models also with reversed sequence of the two factors plant species diversity and functional diversity, as by definition they could not be completely orthogonally designed (because the number of functional groups cannot exceed the number of species, see e.g., Joshi et al. 2000, Marquard et al. 2009b; Tables 2 and 3, and Appendices A and B).

\section{Results}

\section{Pathogen community}

Of the 60 plant species monitored, 45 species were infected with at least one obvious pathogen species, i.e., $92 \%$ of the legumes, $75 \%$ of the tall herb and grass species, and $67 \%$ of the small herb species (Appendix C). In total, we identified 60 pathogen species on our samples (17 leaf-spot disease species, 24 rust species, 11 powdery mildew species, seven downy mildew species, and one smut species, Appendix D; see Plate 1). Tall herbs (25 pathogen species) and legumes (18 pathogen species) hosted most pathogen species followed by small herbs (10 pathogen species), and grasses (seven pathogen species, Appendix D).

By 2006, we identified 60 pathogen species in our survey. Compared to the 48 pathogen species initially described in 2003 (covering the same pathogen groups; G. Hirsch, personal communication), this indicates sufficient establishment time of natural plant-pathogen dynamics since the start of the experiment in 2002. In our surveys, we observed that most of the studied pathogens are specialists at the plant species, genus, or 
TABLE 3. Summary of ANOVA results for effects of plant community diversity and composition on (a) pathogen diversity across seasons and (b) overall infection across seasons.

\begin{tabular}{|c|c|c|c|c|c|c|c|c|c|c|c|c|}
\hline \multirow[b]{2}{*}{ Source of variation } & \multicolumn{3}{|c|}{ Spring } & \multicolumn{3}{|c|}{ Early summer } & \multicolumn{3}{|c|}{ Late summer } & \multicolumn{3}{|c|}{ Autumn } \\
\hline & df & $F$ & $P$ & df & $F$ & $P$ & df & $F$ & $P$ & df & $F$ & $P$ \\
\hline \multicolumn{13}{|l|}{ a) Pathogen diversity across seasons } \\
\hline Block & 3 & 1.68 & 0.182 & 3 & 0.42 & 0.740 & 3 & 0.68 & 0.566 & 3 & 1.22 & 0.308 \\
\hline $\log$ (species diversity) & 1 & 27.30 & $<0.001$ & 1 & 29.19 & $<0.001$ & 1 & 43.89 & $<0.001$ & 1 & 63.41 & $<0.001$ \\
\hline Functional diversity & 1 & 1.77 & 0.189 & 1 & 0.02 & 0.893 & 1 & 0.07 & 0.799 & 1 & 0.34 & 0.561 \\
\hline Functional diversity & 1 & 3.82 & 0.056 & 1 & 13.46 & $<0.001$ & 1 & 17.71 & $<0.001$ & 1 & 23.48 & $<0.001$ \\
\hline $\log$ (species diversity) & 1 & 25.25 & $<\mathbf{0 . 0 0 1}$ & 1 & 15.75 & $<\mathbf{0 . 0 0 1}$ & 1 & 26.25 & $<\mathbf{0 . 0 0 1}$ & 1 & 40.27 & $<0.001$ \\
\hline Presence legumes & 1 & 6.15 & 0.016 & 1 & 8.21 & 0.005 & 1 & 8.02 & 0.006 & 1 & 1.78 & 0.187 \\
\hline Presence grass & 1 & 0.53 & 0.470 & 1 & 1.08 & 0.303 & 1 & 0.20 & 0.657 & 1 & 0.37 & 0.546 \\
\hline Presence tall herbs & 1 & 0.56 & 0.456 & 1 & 0.12 & 0.733 & 1 & 0.25 & 0.620 & 1 & 0.13 & 0.716 \\
\hline Plot & 52 & 2.85 & $<0.001$ & 73 & 3.63 & $<0.001$ & 73 & 5.37 & $<0.001$ & 73 & 3.36 & $<0.001$ \\
\hline Functional identity & 3 & 0.56 & 0.646 & 3 & 1.52 & 0.219 & 3 & 0.81 & 0.491 & 3 & 1.19 & 0.321 \\
\hline Species identity & 55 & 6.99 & $<0.001$ & 55 & 17.38 & $<0.001$ & 55 & 22.14 & $<0.001$ & 55 & 10.14 & $<0.001$ \\
\hline $\log ($ species diversity $) \times$ functional identity & 3 & 1.24 & 0.306 & 3 & 2.32 & 0.086 & 3 & 2.39 & 0.080 & 3 & 1.21 & 0.317 \\
\hline nal diversity $\times$ funct & 3 & 0.75 & 0.530 & 3 & 0.87 & 0.463 & 3 & 0.11 & 0.952 & 3 & 1.36 & 0.265 \\
\hline Functional divers & 3 & 1.59 & 0.203 & 3 & 1.13 & 0.345 & 3 & 1.58 & 0.206 & 3 & 0.16 & 0.923 \\
\hline $\log (\mathrm{sp}$ & 3 & 0.62 & 0.606 & 3 & 2.45 & 0.074 & 3 & 1.32 & 0.277 & 3 & 1.89 & 0.142 \\
\hline legumes $\times$ funct & 2 & 1.01 & 0.378 & 2 & 0.74 & 0.483 & 2 & 0.15 & 0.859 & 2 & 1.59 & 0.218 \\
\hline Presence grass $\times$ functional identity & 2 & 1.51 & 0.242 & 2 & 0.10 & 0.902 & 2 & 0.16 & 0.854 & 2 & 0.24 & 0.791 \\
\hline Pre & 1 & 3.53 & 0.09 & 1 & 0.04 & 0.840 & 1 & 0.29 & 0.600 & 1 & 2.21 & 0.156 \\
\hline & 52 & 1.43 & 0.087 & 52 & 3.28 & $<0.001$ & 50 & 2.98 & $<0.001$ & 53 & 3.10 & $<0.001$ \\
\hline Func & 47 & 1.23 & 0.224 & 51 & 1.35 & 0.075 & 52 & 2.18 & $<0.001$ & 53 & 1.03 & 0.431 \\
\hline diversity $\times$ species identity & 51 & 1.04 & 0.442 & 53 & 1.99 & $<\mathbf{0 . 0 0 1}$ & 52 & 2.15 & $<\mathbf{0 . 0 0 1}$ & 53 & 1.54 & 0.017 \\
\hline ty) $\times$ snecies $i$ & 48 & 1.66 & 0.0 & 50 & 2.67 & $<0.001$ & 50 & 2.99 & $<0.001$ & 53 & 2.59 & $<0.001$ \\
\hline Pre & 28 & 1.39 & 0.142 & 37 & 1.48 & 0.046 & 36 & 1.56 & 0.03 & 36 & 1.58 & 0.025 \\
\hline & 23 & 1.13 & 0.3 & 29 & 1.05 & 0.4 & 28 & 2.15 & 0.0 & 30 & 0.92 & 0.596 \\
\hline Pres & 9 & 0.76 & 0.658 & 16 & 1.39 & 0.148 & 16 & 1.83 & 0.030 & 16 & 1.15 & 0.313 \\
\hline Residuals & 62 & & & 204 & & & 198 & & & 232 & & \\
\hline \multicolumn{13}{|l|}{ b) Overall infection across seasons } \\
\hline & 3 & 2.28 & 0.091 & 3 & 0.24 & 0.867 & 3 & 0.55 & & 3 & 1.61 & 0.195 \\
\hline es diversity) & 1 & 18.14 & $<0.001$ & 1 & 41.19 & $<0.001$ & 1 & 52.44 & $<0.001$ & 1 & 52.51 & $<0.001$ \\
\hline & 1 & 0.01 & 0.939 & 1 & 1.80 & 0.284 & 1 & 0.13 & 0.720 & 1 & 1.64 & 0.205 \\
\hline & 1 & 6.44 & 0.014 & 1 & 10.42 & 0.002 & 1 & 20.59 & $<\mathbf{0 . 0}$ & 1 & 14.82 & $<0.001$ \\
\hline & 1 & 11.70 & 0.001 & 1 & 35.57 & $<\mathbf{0 . 0 0 1}$ & 1 & 31.99 & $<\mathbf{0 . 0 0 1}$ & 1 & 39.32 & $<\mathbf{0 . 0 0 1}$ \\
\hline Pre & 1 & 10.41 & 0.002 & 1 & 7.52 & 0.008 & 1 & 3.10 & 0.082 & 1 & 0.61 & 0.437 \\
\hline Prese & 1 & 0.49 & 0.487 & 1 & 0.36 & 0.550 & 1 & 0.36 & 0.552 & 1 & 2.95 & 0.090 \\
\hline Prese & 1 & 0.03 & 0.855 & 1 & 1.79 & 0.185 & 1 & 1.05 & 0.308 & 1 & 0.95 & 0.333 \\
\hline Plot & 52 & 7.32 & $<0.001$ & 73 & 4.74 & $<0.001$ & 73 & 3.91 & $<0.001$ & 73 & 7.49 & $<0.001$ \\
\hline $\mathrm{Fu}$ & 3 & 1.86 & 0.148 & 3 & 3.05 & 0.036 & 3 & 1.72 & 0.173 & 3 & 0.47 & 0.704 \\
\hline Specie & 55 & 10.65 & $<0.001$ & 55 & 7.16 & $<0.001$ & 55 & 7.53 & $<0.001$ & 55 & 9.12 & $<0.001$ \\
\hline & 3 & 0.80 & 0.499 & 3 & 1.54 & 0.215 & 3 & 3.03 & 0.038 & 3 & 0.79 & 0.508 \\
\hline & 3 & 0.5 & 0.6 & 3 & 0.2 & 0.8 & 3 & 0.1 & 0.9 & 3 & 2.00 & 0.125 \\
\hline & 3 & 1.18 & 0.32 & 3 & 0.69 & 0.564 & 3 & 1.22 & 0.3 & 3 & 0.62 & 0.607 \\
\hline $\log (\mathbf{s}$ & 3 & 0.24 & 0.870 & 3 & 1.18 & 0.326 & 3 & 2.57 & 0.064 & 3 & 1.25 & 0.302 \\
\hline Presence legumes $\times$ functional identity & 2 & 0.95 & 0.399 & 2 & 1.72 & 0.193 & 2 & 1.02 & 0.372 & 2 & 1.73 & 0.192 \\
\hline & 2 & 0.40 & 0.674 & 2 & 0.22 & 0.801 & 2 & 0.76 & 0.479 & 2 & 1.39 & 0.264 \\
\hline ntity & 1 & 4.19 & 0.071 & 1 & 4.96 & 0.041 & 1 & 0.20 & 0.664 & 1 & 0.25 & 0.627 \\
\hline & 52 & 3.41 & $<0.001$ & 52 & 3.14 & $<0.001$ & 50 & 2.44 & $<0.001$ & 53 & 6.80 & $<0.001$ \\
\hline Functional diversity $\times$ species identity & 47 & 2.40 & 0.001 & 51 & 2.32 & $<0.001$ & 52 & 1.38 & 0.061 & 53 & 1.65 & 0.007 \\
\hline Functional diversity $\times$ species identity & 51 & 2.90 & $<0.001$ & 53 & 2.11 & $<0.001$ & 52 & 1.63 & 0.010 & 53 & 3.02 & $<0.001$ \\
\hline & 48 & 2.95 & $<\mathbf{0 . 0 0 1}$ & 50 & 3.40 & $<\mathbf{0 . 0 0 1}$ & $\mathbf{5 0}$ & 2.18 & $<\mathbf{0 . 0 0 1}$ & 53 & 5.43 & $<\mathbf{0 . 0 0 1}$ \\
\hline & 28 & 2.72 & & 37 & 1.87 & 0.003 & 36 & 1.28 & & 36 & 3.82 & $<0.001$ \\
\hline Presence grass $\times$ species identity & 23 & 1.37 & 0.166 & 29 & 1.06 & 0.387 & 28 & 1.16 & 0.279 & 30 & 1.13 & 0.302 \\
\hline Presence tall herb $\times$ species identity & 9 & 0.98 & 0.467 & 16 & 3.41 & $<0.001$ & 16 & 2.20 & 0.006 & 16 & 2.93 & $<0.001$ \\
\hline Residuals & 62 & & & 204 & & & 197 & & & 232 & & \\
\hline
\end{tabular}

Notes: ANOVA results in part (b) are replaced on arcsine-transformed percentage data. Values for functional and species diversity in boldface type were derived from otherwise identical models with reversed sequence of functional and species diversity.

family level (Appendix D) with 49 pathogen species occurring on only one out of our 60 host species, whereas 11 pathogen species infected between two and seven host species. Our more general pathogens infected mainly the plant functional group of legumes (Fabaceae; five pathogen species in total, comprising all pathogen groups but smuts), followed by the plant functional group of grasses (two rust and one leaf-spot species; Appendix D).

Plant pathogens were present throughout the year. Fungal leaf-spot diseases and rust fungi were the dominant pathogen groups in our grassland communities (Fig. 1). However, both presence and infection-level of the different pathogen groups on host plants varied 


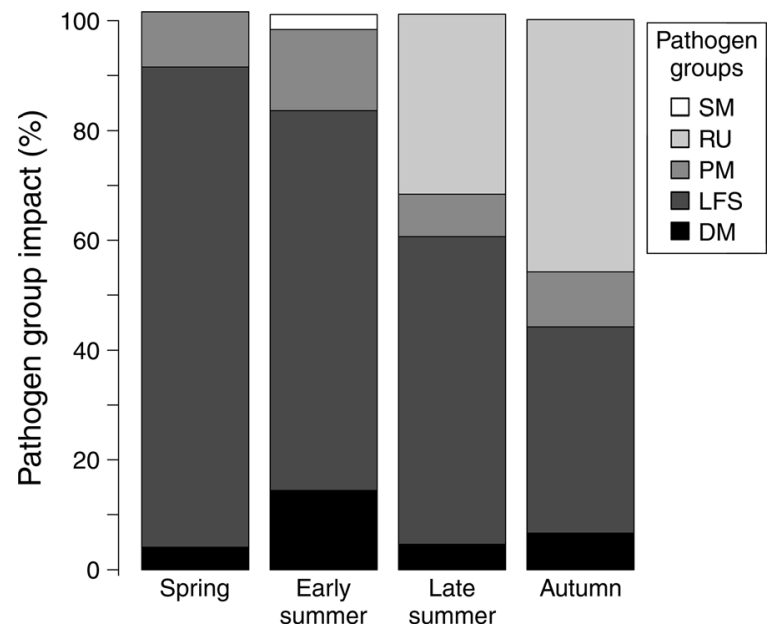

FIG. 1. Portion of overall infection made up of individual pathogen groups for the four survey periods of 82 large experimental plant communities. Pathogen groups are smuts (SM), rusts (RU), powdery mildew (PM), fungal leaf-spot diseases (LFS), and downy mildew (DM).

between seasons (Fig. 1). While leaf-spot diseases decreased, rust fungi increased in presence and infection towards autumn. Downy mildews were most common in the early summer and autumn surveys, and powdery mildews became more common in late summer and autumn (Fig. 1). Neither downy mildews nor powdery mildews nor smuts exceeded $15 \%$ of overall infection throughout the year.

\section{Effects of plant diversity on pathogen presence and infection}

Both plant species diversity and plant functional group diversity positively affected pathogen diversity. Pathogen diversity increased significantly with increasing host species diversity in all seasons (Table 3a, Fig. 2).

In contrast, higher host species diversity and plant functional group diversity had significantly negative effects, both on pathogen presence/absence and overall infection per plant species and plot (Fig. 3, Tables 2a and $3 \mathrm{~b}$ ). Moreover, the likelihood of co-infection of plant individuals by two or more pathogen groups decreased with increasing plant community diversity in all seasons (Table 2b, Appendix F). In all analyses, the factor plant functional diversity was significant when fitted before plant species diversity in the model indicating that plant functional diversity within different plant species diversity levels did not explain any of the variance in pathogen diversity and pathogen severity. In contrast, the factor plant species diversity remained significant even if tested after plant functional diversity indicating the importance of plant species diversity within plant functional diversity levels (Tables 2 and 3 ). Individual plant cover, if added to the model as a measure of host species density, was highly significant for both overall infection and pathogen diversity, both

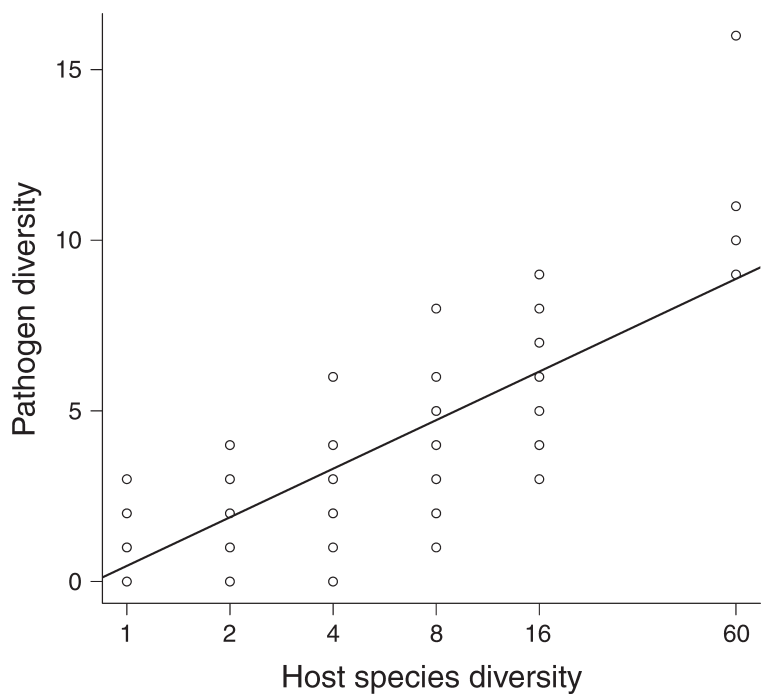

FIG. 2. Log-linear increase of cumulative pathogen diversity (i.e., the cumulative number of pathogen groups per species and plot) with increasing plant species diversity in late summer in 82 large experimental plant communities. Note that the $x$ axis is on a log scale.

when fitted before and after plant species diversity in our model (all $P<0.01$ ). Nevertheless, the factor plant species diversity remained significant even with cover fitted before plant species diversity in our sequential model $\left(F_{1,73}=13.5, P<0.001\right.$ for overall infection, $F_{1,73}$ $=6.7, P=0.01$ for pathogen diversity). Weighting overall infection data by individual plant density in a plot did not qualitatively change the diversity effects detected (Appendix B).

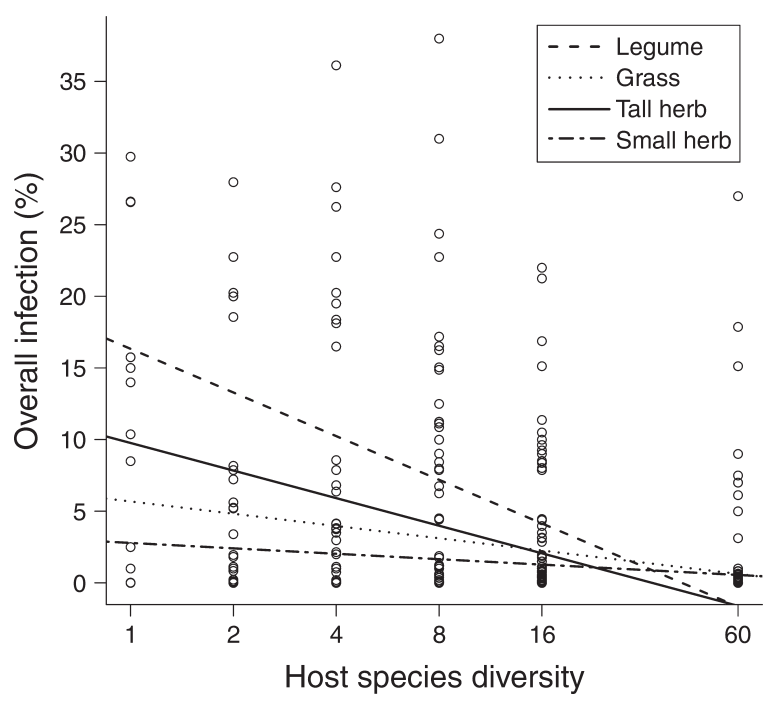

FIG. 3. Log-linear decrease of overall infection in late summer with increasing plant species diversity of 82 large experimental plant communities according to the presence of different plant functional groups. Note that the $x$-axis is on a $\log$ scale. 
The negative effect of host species diversity on overall infection was consistently significant across seasons (Table 3b), even though for individual pathogen groups varying seasonal impacts of plant species diversity on pathogen incidence and pathogen severity were detected (Appendix A). Plant species diversity significantly reduced pathogen incidence (Appendix A: Table A7) and severity for leaf-spot diseases (all seasons, Appendix A: Table A8), rusts (early summer, late summer, autumn), powdery mildews (late summer, autumn), and downy mildews (early summer, autumn), but not for smuts (Appendix A: Table A3).

\section{Effects of plant community composition on pathogen presence and infection}

Presence of pathogens, pathogen diversity (all seasons except for autumn), and overall infection (spring and early summer) all were higher in plots with legumes (Fig. 4, Tables 2a, 3a, b). In contrast, the presence or absence of other plant functional groups was less important as an explanatory variable for pathogen incidence and severity (Appendix A). Accordingly, the presence of tall herbs had significant effects only on the incidence of downy mildew (early and late summer data; Appendix A: Table A5) and the presence of grasses significantly affected rust severity in autumn (Appendix A: Table A2) and smut incidence in early summer (Appendix A: Table A3).

\section{DisCUSSION}

\section{Effects of plant species diversity on pathogen group diversity and infection}

We observed pathogen-group presence and overall infection levels to change between seasons, in agreement with studies reporting natural fluctuations between seasons or between years depending on pathogen lifecycle, nutrient availability or climatic conditions (Pehkonen and Tolvanen 2008). As hypothesized, we observed the more diverse plant communities harbored a higher diversity of obligate fungal pathogens (Fig. 2) through an increase in potential hosts. Our results correspond with studies reporting diverse plant communities to sustain increased pathogen communities for both specialist pathogens (due to the presence of pathogen-prone species [Mitchell et al. 2002, Keesing et al. 2006]) and generalist pathogens (due to the presence of alternative hosts, increasing the probability of plant-mediated apparent competition [Power and Mitchell 2004, Mitchell and Power 2006]). Thus, higher pathogen community diversity can be expected in diverse plant communities with the shape and strength of the relationship depending on pathogen specialization and host species identity in terms of pathogen proneness within community.

In contrast to pathogen diversity, our data demonstrated negative diversity dependence for pathogen presence, incidence and severity; with increasing plant species diversity in the grassland communities, fewer plant species and fewer plant individuals per host species

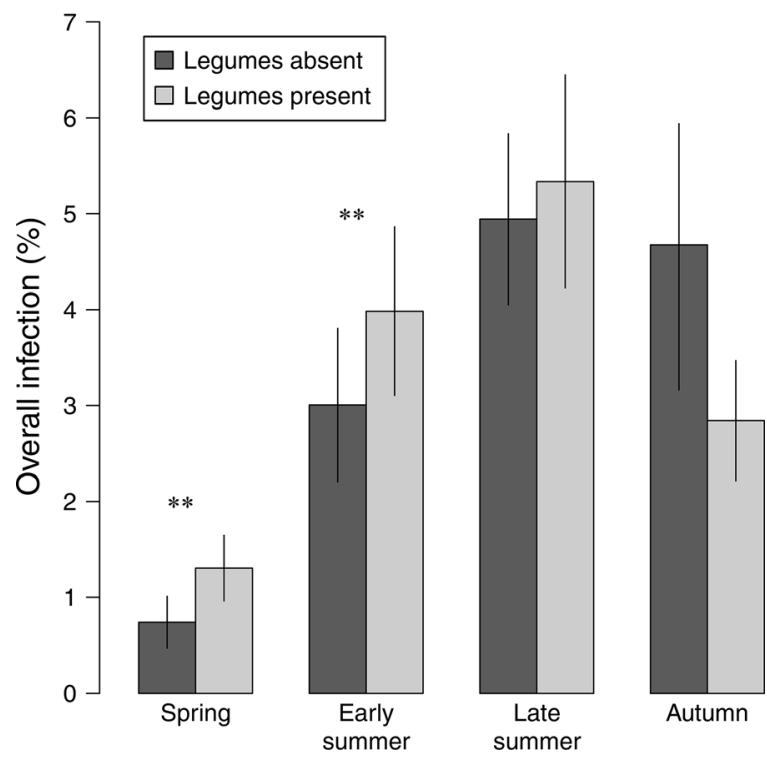

FIG. 4. Impact of the presence of legumes on overall infection across diversity levels (\%) in all four survey periods. Error bars show SE. ${ }^{* *} P<0.01$.

were infected with a lower percentage of damaged plant tissue (Appendix E). In the Jena Experiment, increased plant species diversity was associated with reduced plant species densities (Marquard et al. 2009b) and increased spatial heterogeneity. Other studies have shown that the neighborhood a plant is growing in and environmental conditions can affect pathogen infection (e.g., Mulder et al. 2008). In our case, we suspect that the more diverse plots simply had more barriers to infection. The reduction in the probability of encountering the right host, reduces the probability of initial infection and further transmission of inoculum. This problem would be particularly acute for pathogen specialists (Laine 2004). Additionally, in more diverse grassland communities, we also observed infected plant species to be less likely to be infected by multiple pathogens (Table $2 b$, Appendix F). Co-infection of pathogens is equally governed by initial host encounter and non-host shielding that limits pathogen spread, which also increases competition between pathogens for shared host tissue (Finckh et al. 2000, Barrett et al. 2009, Hamelin et al. 2011).

While individual host species may vary in key traits directly affecting pathogen infection such as resistance or tolerance (Barrett et al. 2009), overall community structure and architecture may additionally alter pathogen presence and transmission (Mitchell 2003). Complementary resource use with increased plant species and functional diversity influences community structure and three-dimensional space-filling capacity (Spehn et al. 2000), and thus microclimatic conditions within the plant community. While blocking further external aerial inoculum transmission for understory species, a closed canopy cover in diverse plant communities may provide 


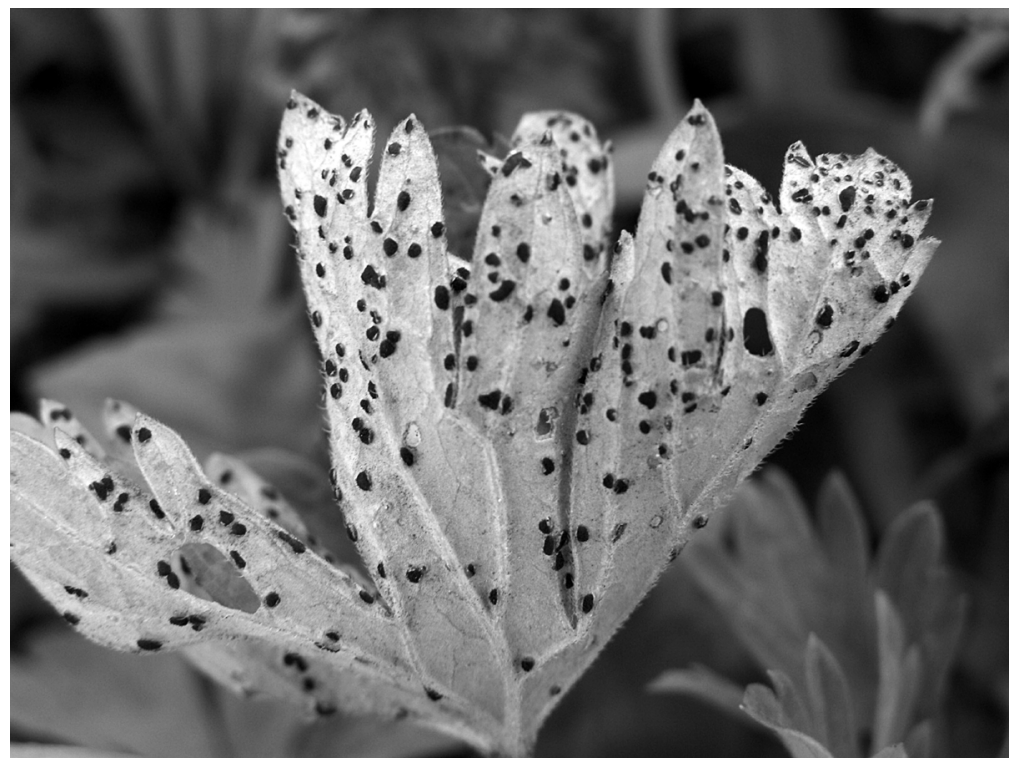

Plate 1. Rust infection (Uromyces geranii, see Appendix D) of the tall herb Geranium pratense. Photo credit: T. Rottstock.

a favorable environment for pathogen development via increased humidity for spore germination (Chapin et al. 2003) and leaf wettability (Bradley et al. 2003).

Our data underline the significance of plant species diversity for pathogen diversity, presence, and overall infection. While inoculum interception has been conceptually acknowledged in the current literature (Burdon et al. 2006, Mundt et al. 2011) as alternative mechanism determining pathogen infection and presence, experimental proof is scarce (Mitchell et al. 2002, Burdon et al. 2006). This may be due to the prevalence of monoculture studies focusing on genotype mixtures but missing the complex spatial heterogeneity typical of diverse species communities. By incorporating plant species cover as species density estimate in our model we observed plant species diversity to remain highly significant for both pathogen diversity and overall infection. This indicates that diversity-related mechanisms other than pure host species frequency i.e., better three-dimensional space filling and greater biomass density with increasing plant species diversity (Spehn et al. 2000, Mundt et al. 2011) and concomitant changes in microclimate also affect pathogen presence and overall infection in plant communities.

\section{The role of host functional group identity for pathogen presence and infection}

Increased plant species richness may buffer abiotic stress for limiting resources among plants through complementarity and facilitation effects (Spehn et al. 2002, Neumann et al. 2004, Pekhonen and Tolvanen 2008), thus influencing plant susceptibility and infection risk due to alterations nutritional state (Finckh et al. 2000, Chen et al. 2010). In addition, increasing plant species diversity leads to increasing spatial heterogeneity due to different plant morphologies. Here, we observed the presence of the plant functional groups of tall herbs and legumes to contribute the largest proportion to overall community infection. As they were among the dominant plant species in mixtures with high biomass contributions (Roscher et al. 2007, Marquard et al. $2009 b$ ), we assume them to be easily exposed to inoculum rain. In addition, they are effectively shielding smaller neighboring plant species from their associated pathogens, thus reducing pathogen presence and incidence for understory species in diverse communities. For example, our results showed the tall legumes with a relatively large surface area (Onobrychis viciifolia, Medicago $\times$ varia, and Trifolium pratense) to be highly susceptible to fungal pathogen attack.

Besides host growth structure, nutrient availability may influence pathogen development and thus severity. Increased leaf-nitrogen content may favor higher pathogen incidence both due to increased target area of more vigorously growing plants and pathogen severity as pathogen success fully depends on their host, especially for nitrogen (Solomon et al. 2003, Neumann et al. 2004, Nordin et al. 2005). While nitrogen fertilization has been demonstrated to increase pathogen severity, the effect size varies, and depends on host characteristics, pathogen identity, and season (Hatcher and Paul 2000, Han et al. 2008, Newton et al. 2010). The presence of legumes as a nitrogen-fixing plant functional group can also increase within-plant nutrient status and nutrient availability for neighboring plant species within communities (Spehn et al. 2002), thus altering nutritional levels and growth structure through increased leaf area of neighboring plant species (Roscher et al. 2007, Marquard et al. 2009a, $b$, Schmidtke et al. 2010). We observed the 60 species mixtures where both tall herb and legume species are 
present to have the lowest pathogen incidence and severity. Thus, we believe that besides host density the increased spatial heterogeneity (i.e., growth structure reducing inoculum transmission and affecting microclimate) in the lower vegetation layer to be the main driver for regulating pathogen presence and infection. In turn, pathogens may well affect plant community dynamics in the longer run by restraining dominant species via increased pathogen pressure (Allan et al. 2010).

In our plant communities, at least $75 \%$ of plant species encountered fungal pathogen attack in the course of a year. The presence of pathogen groups and extent of plant infection varied between seasons reflecting variation in fungal pathogen life cycles and weather conditions for pathogen infection and spread. However, pathogen presence and infection were strongly and consistently influenced by a combination of plant species diversity and plant community composition effects: Higher plant species diversity promoted pathogen diversity, while it simultaneously decreased pathogen incidence and severity. In addition, in species-rich communities, plant individuals were less likely to be infected by multiple pathogens. We conclude that multihost-multi-pathogen communities are largely shaped by plant species diversity and in turn, due to differential effects on their host plants, are very likely to feed back on plant community assembly.

\section{ACKNowledgments}

We thank the initiators, coordinators, and gardeners of the Jena Experiment for all their work for establishing and maintaining the experimental plots, especially Wolfgang W. Weisser, Bernhard Schmid, Ernst-Detlef Schulze, Christiane Roscher, and Alexandra Weigelt. Special thanks to Gerald Hirsch for his initial survey and introduction to the fungal plant pathogens of the field site in 2005 . We thank two anonymous reviewers for their constructive and valuable comments, which helped us largely to further improve our manuscript. Markus Fischer acknowledges funding by the German Research Foundation DFG (in FOR 456 and FOR1451). Tanja Rottstock was co-funded by the University of Potsdam (Kurzstipendium der Universität Potsdam: Förderung zum Abschluss des Promotionsvorhabens).

\section{Literature Cited}

Adler, F. R., and H. C. Mueller-Landau. 2005. When do localized natural enemies increase species richness? Ecology Letters 8:438-447.

Agrios, G. N. 2005. Plant pathology. Fourth edition. Academic Press, London, UK.

Alexander, H. M. 2010. Disease in natural plant populations, communities, and ecosystems: insights into ecological and evolutionary processes. Plant Disease 94:492-503.

Allan, E., J. van Ruijven, and M. J. Crawley. 2010. Foliar fungal pathogens and grassland biodiversity. Ecology 91: 2572-2582.

Altizer, S., D. Harvell, and E. Friedle. 2003. Rapid evolutionary dynamics and disease threats to biodiversity. Trends in Ecology and Evolution 18:589-596.

Altizer, S., and A. B. Pedersen. 2008. Host-pathogen evolution, biodiversity and disease risks for natural populations. Pages 259-278 in S. Caroll and C. Fox, editors. Conservation biology: evolution in action. Oxford University Press, Oxford, UK.
Barrett, L. G., J. M. Kniskern, N. Bodenhausen, W. Zhang, and J. Bergelson. 2009. Continua of specificity and virulence in plant host-pathogen interactions: causes and consequences. New Phytologist 183:513-529.

Blaisdell, G. K., and B. A. Roy. 2013. Two tests of enemy release of commonly co-occurring bunchgrasses native in Europe and introduced in the United States. Biological Invasions 16:833-842.

Borer, E. T., C. E. Mitchell, A. G. Power, and E. W. Seabloom. 2009. Consumers indirectly increase infection risk in grassland food webs. Proceedings of the National Academy of Sciences USA 106:503-506.

Bradley, D. J., G. S. Gilbert, and I. M. Parker. 2003. Susceptibility of clover species to fungal infection: the interaction of leaf surface traits and environment. American Journal of Botany 90:857-864.

Brandenburger, W. 1985. Parasitische Pilze an Gefäßpflanzen in Europa. Gustav Fischer Verlag, Stuttgart, Germany.

Braun, U. 1982. Die Rostpilze (Uredinales) der Deutschen Demokratischen Republik. Feddes Repertertorium 93:213333.

Braun, U. 1995a. A monograph of Cercosporella, Ramularia and allied genera (Phytopathogenic Hyphomycetes). Volume 2. IHW-Verlag, Eching, Germany.

Braun, U. 1995b. The powdery mildews (Erysiphales) of Europe. Gustav Fischer Verlag, Jena, Germany.

Braun, U., and R. T. A. Cook. 2012. Taxonomy manual of the Erysiphales (powdery mildews). CBS Biodiversity Series 11 . CBS, Utrecht, Netherlands.

Burdon, J. J., and G. A. Chilvers. 1982. Host density as a factor in plant-disease ecology. Annual Review of Phytopathology 20:143-166.

Burdon, J. J., P. H. Thrall, and L. Ericson. 2006. The current and future dynamics of disease in plant communities. Annual Review of Phytopathology 44:19-39.

Cardinale, B. J., K. L. Matulich, D. U. Hooper, J. E. Byrnes, E. Duffy, L. Gamfeldt, P. Balvanera, M. I. O'Connor, and A. Gonzalez. 2011. The functional role of producer diversity in ecosystems. American Journal of Botany 98:572-592.

Carlsson-Granér, U., and P. H. Thrall. 2002. The spatial distribution of plant populations, disease dynamics and evolutionary resistance. Oikos 97:97-110.

Chapin, F. S., III. 2003. Effects of plant traits on ecosystem and regional processes: a conceptual framework for predicting the consequences of global change. Annals of Botany 91:455463.

Chen, Y., D. M. Olson, and J. R. Ruberson. 2010. Effects of nitrogen fertilization on tritrophic interactions. ArthropodPlant Interactions 4:81-94.

Ellis, M. B., and J. P. Ellis. 1997. Microfungi on land plants. Richmond Publishing, Slough, UK.

Elton, C. S. 1958. The ecology of invasions by animals and plants. Methuen, London, UK.

Fargione, J., D. Tilman, R. Dybzinski, J. Hille Ris Lambers, C. Clark, W. S. Harpole, J. M. H. Knops, P. B. Reich, and M. Loreau. 2007. From selection to complementarity: shifts in the causes of biodiversity-productivity relationships in a long-term biodiversity experiment. Proceedings of the Royal Society B 274:871-876.

Ferrer, A., and G. S. Gilbert. 2003. Effect of tree host species on fungal community composition in a tropical rain forest in Panama. Diversity and Distributions 9:455-468.

Finckh, M. R., et al. 2000. Cereal variety and species mixtures in practice, with emphasis on disease resistance. Agronomie 20:813-837.

Flombaum, P., and O. E. Sala. 2012. Effects of plant species traits on ecosystem processes: experiments in the Patagonian steppe. Ecology 93:227-234.

Garrett, A., and C. C. Mundt. 1999. Epidemiology in mixed host populations. Phytopathology 89:984-990. 
Gäumann, E. 1959. Die Rostpilze Mitteleuropas mit besonderer Berücksichtigung der Schweiz. Büchler, Bern, Switzerland.

Gilbert, G. S. 2002. Evolutionary ecology of plant diseases in natural ecosystems. Annual Review of Phytopathology 40: $13-43$.

Gubsch, M., C. Roscher, G. Gleixner, M. Habekost, A. Lipowsky, B. Schmid, E. R. N. S. Schulze, S. Steinbeiss, and N. Buchmann. 2011. Foliar and soil $\delta^{15} \mathrm{~N}$ values reveal increased nitrogen partitioning among species in diverse grassland communities. Plant, Cell and Environment 34:895-908.

Haddad, N. M., G. M. Crutsinger, K. Gross, J. Haarstad, and D. Tilman. 2011. Plant diversity and the stability of foodwebs. Ecology Letters 14:42-46.

Hamelin, F. M., M. Castel, S. Poggi, D. Andrivon, and L. Mailleret. 2011. Seasonality and the evolutionary divergence of plant parasites. Ecology 92:2159-2166.

Han, X., S. P. Dendy, K. A. Garrett, L. Fang, and M. D. Smith. 2008. Comparison of damage to native and exotic tallgrass prairie plants by natural enemies. Plant Ecology 198: $197-210$

Hatcher, P. E., and N. D. Paul. 2000. Beetle grazing reduces natural infection of Rumex obtusifolius by fungal pathogens. New Phytologist 146:325-333.

Hooper, D. U. 1998. The role of complementarity and competition in ecosystem responses to variation in plant diversity. Ecology 79:704-719.

Hudson, P. J., A. P. Dobson, and K. D. Lafferty. 2006. Is a healthy ecosystem one that is rich in parasites? Trends in Ecology and Evolution 21:381-385.

Johnson, P. T. J., R. B. Hartson, D. J. Larson, and D. R. Sutherland. 2008. Diversity and disease: community structure drives parasite transmission and host fitness. Ecology Letters 11:1017-1026.

Joshi, J., D. Matthies, and B. Schmid. 2000. Root hemiparasites and plant diversity in experimental grassland communities. Journal of Ecology 88:634-644.

Joshi, J., S. J. Otway, J. Koricheva, A. B. Pfisterer, J. Alphei, B. A. Roy, M. Scherer-Lorenzen, B. Schmid, E. Spehn, and A. Hector. 2004. Bottom-up effects and feedbacks in simple and diverse experimental grassland communities. Pages 115 134 in W. W. Weisser and E. Siemann, editors. Insects and ecosystem function. Springer Verlag, Berlin, Germany.

Keesing, F., et al. 2010. Impacts of biodiversity on the emergence and transmission of infectious diseases. Nature 468:647-652.

Keesing, F., R. D. Holt, and R. S. Ostfeld. 2006. Effects of species diversity on disease risk. Ecology Letters 9:485-498.

King, K. C., and C. M. Lively. 2012. Does genetic diversity limit disease spread in natural host populations? Heredity 109:199-203.

Klenke, F. 1998. Sammel- und Bestimmungshilfen für phytoparasitische Kleinpilze in Sachsen. Berichte der Arbeitsgemeinschaft Sächsischer Botaniker Neue Folge 16:1-256.

Knops, J. M. H., et al. 1999. Effects of plant species richness on invasion dynamics, disease outbreaks, insect abundances and diversity. Ecology Letters 2:286-293.

Koricheva, J., C. P. H. Mulder, B. Schmid, J. Joshi, and K. Huss-Danell. 2000. Numerical responses of different trophic groups of invertebrates to manipulations of plant diversity in grasslands. Oecologia 125:271-282.

Kranz, J. 1990. Tansley Review No 28. Fungal diseases in multispecies plant communities. New Phytologist 116:383405.

Krupinsky, J. M., K. L. Bailey, M. P. McMullen, B. D. Gossen, and T. K. Turkington. 2002. Managing plant disease risk in diversified cropping systems. Agronomy Journal 94:198-209.

Laine, A. L. 2004. Resistance variation within and among host populations in a plant-pathogen metapopulation: implications for regional pathogen dynamics. Journal of Ecology 92: $990-1000$
Latz, E., N. Eisenhauer, B. C. Rall, E. Allan, C. Roscher, S. Scheu, and A. Jousset. 2012. Plant diversity improves protection against soil-borne pathogens by fostering antagonistic bacterial communities. Journal of Ecology 100:597604.

Mace, G. M., et al. 2010. Biodiversity targets after 2010. Current Opinion in Environmental Sustainability 2:3-8.

Marquard, E., A. Weigelt, C. Roscher, M. Gubsch, A. Lipowsky, and B. Schmid. 2009a. Positive biodiversityproductivity relationship due to increased plant density. Journal of Ecology 97:696-704.

Marquard, E., A. Weigelt, V. M. Temperton, C. Roscher, J. Schumacher, N. Buchmann, M. Fischer, W. W. Weisser, and B. Schmid. 2009b. Plant species richness and functional composition drive overyielding in a six-year grassland experiment. Ecology 90:3290-3302.

Mitchell, C. E. 2003. Trophic control of grassland production and biomass by pathogens. Ecology Letters 6:147-155.

Mitchell, C. E., and A. G. Power. 2006. Disease dynamics in plant communities. Pages 58-72 in S. C. Collinge and C. Ray, editors. Disease ecology: community structure and pathogen dynamics. Oxford University Press, Oxford, UK.

Mitchell, C. E., D. Tilman, and J. V. Groth. 2002. Effects of grassland plant species diversity, abundance, and composition on foliar fungal disease. Ecology 83:1713-1726.

Moore, S. M., and E. T. Borer. 2012. The influence of host diversity and composition on epidemiological patterns at multiple spatial scales. Ecology 93:1095-1105.

Mulder, C. P. H., J. Koricheva, K. Huss-Danell, P. Högberg, and J. Joshi. 1999. Insects affect relationships between plant species richness and ecosystem processes. Ecology Letters 2: 237-246.

Mulder, C. P., B. A. Roy, and S. Güsewell. 2008. Herbivores and pathogens on Alnus viridis subsp. fruticosa in interior Alaska: effects of leaf, tree, and neighbour characteristics on damage levels. Botany 86:408-421.

Mundt, C. C., K. E. Sackett, and L. R. D. Wallace. 2011. Landscape heterogeneity and disease spread: experimental approaches with a plant pathogen. Ecological Applications 21:321-328.

Neumann, S., N. D. Paveley, F. D. Beed, and R. SylvesterBradley. 2004. Nitrogen per unit leaf area affects the upper asymptote of Puccinia striformis f. sp. tritici epidemics in winter wheat. Plant Pathology 53:725-732.

Newton, A. C., C. Gravouil, and J. M. Fountaine. 2010. Managing the ecology of foliar pathogens: ecological tolerance in crops. Annals of Applied Biology 157:343-359.

Ney, B., M. O. Bancal, P. Bancal, I. J. Bingham, J. Foulkes, D. Gouache, N. Paveley, and J. Smith. 2013. Crop architecture and crop tolerance to fungal diseases and insect herbivory. Mechanisms to limit crop losses. European Journal of Plant Pathology 135:561-580.

Nordin, A., J. Strengbom, and L. Ericson. 2005. Responses to ammonium and nitrate additions by boreal plants and their natural enemies. Environmental Pollution 141:167-174.

Oberforster, M. 2001. Bonitieren: den Krankheitsbefall von Getreide richtig einschätzen. Österreichische Agentur für Gesundheit und Ernährungssicherheit GmbH, Vienna, Austria.

Pehkonen, T., and A. Tolvanen. 2008. Relationships between Vaccinium vitis-idaea and the frequency of its fungal pathogen Exobasidium splendidum, and the environment. Arctic, Antarctic, and Alpine Research 40:561-567.

Pfleeger, T. G., and C. C. Mundt. 1998. Wheat leaf rust severity as affected by plant density and species proportion in simple communities of wheat and wild oats. Phytopathology 88: 708-714.

Power, A. G., and C. E. Mitchell. 2004. Pathogen spillover in disease epidemics. American Naturalist 164:S79-S89.

R Development Core Team. 2008. R: A language and environment for statistical computing. R Foundation for 
Statistical Computing, Vienna, Austria. http://www. R-project.org

Roscher, C., J. Schumacher, J. Baade, W. Wilcke, G. Gleixner, W. W. Weisser, B. Schmid, and E. D. Schulze. 2004. The role of biodiversity for element cycling and trophic interactions: an experimental approach in a grassland community. Basic and Applied Ecology 5:107-121.

Roscher, C., J. Schumacher, W. W. Weisser, B. Schmid, and E. D. Schulze. 2007. Detecting the role of individual species for overyielding in experimental grassland communities composed of potentially dominant species. Oecologia 154: $535-549$.

Roy, B. A., S. Güsewell, and J. Harte. 2004. Response of plant pathogens and herbivores to a warming experiment. Ecology 85:2570-2581.

Scherber, C., et al. 2010a. Bottom-up effects of plant diversity on multitrophic interactions in a biodiversity experiment. Nature 468:553-556.

Scherber, C., et al. 2010b. Biodiversity and belowground interactions mediate community invasion resistance against a tall herb invader. Journal of Plant Ecology 3:99-108.

Schmidtke, A., T. Rottstock, U. Gaedke, and M. Fischer. 2010. Plant community diversity and composition affect individual plant performance. Oecologia 164:665-677.

Schüepp, H. 1959. Untersuchungen über Pseudopezizoideae sensu Nannfeldt. Phytopathologische Zeitschrift 36:213-269.
Skelsey, P., K. A. With, and K. A. Garrett. 2013. Why dispersal should be maximized at intermediate scales of heterogeneity. Theoretical Ecology 6:203-211.

Snedecor, G. W., and W. G. Cochran. 1980. Statistical methods. Seventh edition. Iowa State University Press, Ames, Iowa, USA.

Solomon, P. S., K. C. Tan, and R. P. Oliver. 2003. The nutrient supply of pathogenic fungi, a fertile field for study. Molecular Plant Pathology 4:203-210.

Spehn, E. M., J. Joshi, B. Schmid, M. Diemer, and C. Körner. 2000. Above-ground resource use increases with plant species richness in experimental grassland ecosystems. Functional Ecology 14:326-337.

Spehn, E. M., et al. 2002. The role of legumes as a component of biodiversity in a cross-European study of grassland biomass nitrogen. Oikos 98:205-218.

Trigiano, R. N., M. T. Windham, and A. S. Windham. 2004. Plant pathology: concepts and laboratory exercises. CRC Press, New York, New York, USA.

van Ruijven, J., G. B. De Deyn, and F. Berendse. 2003. Diversity reduces invasibility in experimental plant communities: the role of plant species. Ecology Letters 6:910-918.

Vánky, K. 1994. European smut fungi. Gustav Fischer Verlag, Stuttgart, Germany.

Weigelt, A., et al. 2010. The Jena Experiment: six years of data from a grassland biodiversity experiment. Ecology 91:930931.

\section{Supplemental Material}

\section{Appendix A}

ANOVA results for the effects of plant community diversity and composition on pathogen group incidence and severity (Ecological Archives E095-168-A1).

\section{Appendix B}

ANOVA results for overall infection weighted by individual plant cover (Ecological Archives E095-168-A2).

Appendix C

List of all plant species with their number of associated pathogens (Ecological Archives E095-168-A3).

Appendix D

Complete list of sampled pathogen species across seasons (Ecological Archives E095-168-A4).

\section{Appendix $\mathbf{E}$}

Log-linear decrease of overall mean pathogen incidence (Ecological Archives E095-168-A5).

\section{Appendix F}

Log-linear decrease of co-infection (Ecological Archives E095-168-A6). 